\title{
Rola organizacji pozarządowych we wspieraniu kształtowania środowiska akademickiego przyjaznego osobom z niepełnosprawnościami oraz zwiększaniu szans zawodowych absolwentów z niepełnosprawnościami
}

Fundacja Instytut Rozwoju Regionalnego (FIRR) jest organizacją pozarządową typu non-profit o statusie organizacji pożytku publicznego, działającą od 26 sierpnia 2003 roku w celu wspierania osób z niepełnosprawnościami, w szczególności z dysfunkcją wzroku. Wspieramy szkoleniowo i doradczo osoby z niepełnosprawnościami $\mathrm{w}$ ich niezależnym życiu. Propagujemy pełny udział w społeczeństwie, w tym włączającą edukację, upowszechniamy wiedzę o niepełnosprawności i dostępności, promujemy użycie najnowszych technologii. Wydajemy tematyczne czasopismo i publikacje oraz prowadzimy portal i radio internetowe. Współpracujemy z Parlamentem, urzędami centralnymi, samorządami, uczelniami i pracodawcami, a także z podmiotami zagranicznymi w ramach licznych projektów ponadnarodowych. 
Naszym celem jest eliminacja m.in. takich zjawisk negatywnych, jak:

- brak wiedzy o specyficznych potrzebach osób z niepełnosprawnościami,

- deficyt woli współpracy,

- niski poziom świadomości osób z niepełnosprawnościami,

- brak woli (wiedzy na temat) praktycznego zastosowania prawa,

- niedostosowana infrastruktura,

- niski odsetek absolwentów z niepełnosprawnościami,

- wąskie (formalne) rozumienie niepełnosprawności.

Wśród naszych działań wymienić można:

- rehabilitację i szkolenia dla osób z niepełnosprawnością,

- szkolenia dla otoczenia,

- badania i ekspertyzy,

- publikacje,

- lobbing na rzecz zmian prawnych,

- akcje informacyjno-promocyjne,

- szkolenia zewnętrzne dla osób, które w swojej pracy mają częsty kontakt z osobami z niepełnosprawnościami (np. dostępność stron internetowych i dokumentów elektronicznych, dostępność branży turystycznej, zwiększanie świadomości dotyczącej niepełnosprawności).

Dotychczasowa współpraca FIRR z uczelniami wyższymi potwierdza, iż istnieje zapotrzebowanie na ciągłe podnoszenie wiedzy i kompetencji w zakresie budowania środowiska akademickiego przyjaznego studentom z niepełnosprawnościami, stwarzania możliwości równego dostępu do oferty uczelni oraz prowadzenia wsparcia odpowiadającego obecnym wymaganiom rynku pracy. Działając na rzecz zwiększenia dostępności szkolnictwa wyższego dla osób z niepełnosprawnościami, realizujemy:

- konferencje (przede wszystkim coroczną, ogólnopolską konferencję Petno(s)prawny Student),

- szkolenia z zakresu zwiększenia dostępności uczelni dla studentów z niepełnosprawnościami,

- działania konsultacyjne (w zakresie nowoczesnych technologii, dostępności stron internetowych, dostosowania materiałów dydaktycznych itp.),

- projekty transferu dobrych praktyk we współpracy międzynarodowej,

- działania w obszarze prawa (nowelizacja Ustawy Prawo o Szkolnictwie Wyższym, badanie regulaminów i programów nauczania),

- projekty prozatrudnieniowe. 
Zgodnie z unijną strategią wzrostu Europa $2020^{1}$ oraz zaleceniami Rady Unii Europejskiej dla Polski ${ }^{2}$ konieczne jest zapewnienie młodzieży stałego miejsca na rynku pracy, zwiększenie dostępności szkolnictwa zawodowego i wyższego oraz przeciwdziałanie wykluczeniu społecznemu, zwłaszcza $\mathrm{w}$ dziedzinie zatrudnienia i podnoszenia kwalifikacji. Zadanie to wpisuje się także w realizację krajowej Strategii Rozwoju Kapitału Ludzkiego (uchwała nr 104 Rady Ministrów z dnia 18 czerwca 2013 r. w sprawie przyjęcia Strategii Rozwoju Kapitału Ludzkiego 202033), której trzeci cel szczegółowy dotyczy poprawy sytuacji osób i grup zagrożonych wykluczeniem społecznym. Do jego realizacji ma się przyczynić m.in. wyrównanie szans edukacyjnych w kontekście zmieniających się potrzeb rynku pracy oraz „dostosowanie oferty dydaktycznej i kierunków kształcenia do potrzeb rynku pracy przez zacieśnianie współpracy przedsiębiorstw ze sferą edukacji oraz umożliwienie uczniom i studentom praktycznej nauki w przedsiębiorstwach w ramach bardziej rozwiniętego systemu praktyk zawodowych i staży".

Różnica w poziomie wykształcenia jest jednym z podstawowych czynników decydujących o gorszej pozycji zawodowej i społecznej osób z niepełnosprawnościami. Pomimo pozytywnych tendencji średnia osób z niepełnosprawnościami z wyższym wykształceniem jest $\mathrm{w}$ dalszym ciągu dużo niższa niż analogiczna średnia wśród osób pełnosprawnych ${ }^{4}$. Osobom z niepełnosprawnościami wciąż często odmawia się prawa do autonomicznego decydowania o swojej przyszłości, wpychając je w ramy systemu opiekuńczego $^{5}$. Instytucje podejmują decyzje i działania bez uwzględnienia ich opinii, w efekcie mijając się z ich rzeczywistymi potrzebami. Taka sytuacja ma

1 European Commission, Europe 2020. A strategy for smart, sustainable and inclusive growth, http://ec.europa.eu/eu2020/pdf/COMPLET\%20EN\%20BARROSO\%20\%20\%20007\% 20-\%20Europe\%202020\%20-\%20EN\%20version.pdf (dostęp: 30.06.2015).

2 Rada Unii Europejskiej, Zalecenie Rady w sprawie krajowego programu reform Polski z 2013 r. oraz zawierające opinię Rady na temat przedstawionego przez Polskę programu konwergencji na lata 2012-2016, http://ec.europa.eu/europe2020/pdf/nd/csr2013 poland_pl.pdf (dostęp: 30.06.2015).

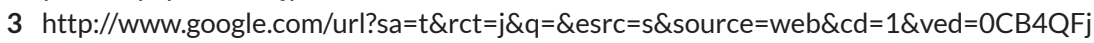
AA\&url=http\%3A\%2F\%2Fisip.sejm.gov.pl\%2FDownload\%3Fid\%3DWMP20130 000640\%26type\%3D2\&ei=XaCTVdGeEYHXyQPRsZCYAw\&usg=AFQjCNGbwnsVLIz Ed6JxqOcznEoO5R8igA\&bvm=bv.96952980,d.bGQ (dostęp: 30.06.2015).

4 Analiza własna danych Głównego Urzędu Statystycznego na podstawie dokumentu Badanie Aktywności Ekonomicznej Ludności [dalej: BAEL].

5 Lucjan Klyszcz, Pułapka świadczeniowa a aktywność zawodowa i społeczna osób niepetnosprawnych, Kraków 2011, wersja elektroniczna dostępna pod linkiem: http://www.firr. org.pl/uploads/PUB/Pulapka_swiadczeniowa.pdf. 
236 miejsce niestety również na poziomie edukacji wyższej, która co prawda już bardzo otwarła się na studentów z niepełnosprawnościami, niestety główne kierunki tych działań nadal bywają wyznaczane bez konsultacji z samymi zainteresowanymi. Rodzi to wiele problemów i paradoksów, a przede wszystkim frustrację wśród studentów z niepełnosprawnościami i bezpośrednio odpowiedzialnych za ich wsparcie pracowników uczelni.

Studenci z niepełnosprawnościami spotkają się z brakiem akceptacji i zrozumienia dla specyfiki ich potrzeb, nie tylko ze strony innych studentów, ale także wykładowców i pracowników uczelnianej administracji. Zwalczanie uprzedzeń i krzywdzących osoby z niepełnosprawnościami stereotypów, kształtowanie postaw tolerancji i zrozumienia wymaga pracy ze wszystkimi członkami akademickiej społeczności. Podstawowym problemem zgłaszanym przez studentów i przedstawicieli uczelni jest brak informacji, możliwości wymiany doświadczeń, wiedzy o dostępnych rozwiązaniach technicznych, sposobach interpretacji przepisów oraz możliwych źródłach finansowania działań dostosowujących. Problemem, który dotyka wszystkich studentów, ale najbardziej osoby z niepełnosprawnościami, jest płynne przejście ze studiów na rynek pracy. Jest ono dodatkowo utrudnione przez wciąż funkcjonujące w otoczeniu stereotypy. Co więcej, ogromna konkurencja wśród młodych sprawia, że studia wyższe przestały być gwarantem zatrudnienia. Dziś pracodawcy zwracają szczególną uwagę na zdobyte w czasie studiów doświadczenie oraz rozwinięte kompetencje miękkie. Wielu pracodawców systematycznie skarży się na problemy związane z rekrutacją osób do pracy. Główną ich przyczyną są niespełnione wymagania stawiane kandydatom, szczególnie w zakresie posiadanych kompetencji. Najczęściej wskazywane deficyty to: brak umiejętności organizacyjnych (organizacja pracy i przejawianie inicjatywy, terminowość) oraz interpersonalnych (kontakty z innymi ludźmi). W przypadku ofert pracy doświadczenie zawodowe kandydatów jest najważniejszym kryterium selekcyjnym. Według raportu Pracodawcy o rynku pracy ${ }^{6}$ większość pracodawców podczas rekrutacji zwraca uwagę na dotychczasową aktywność kandydatów na rynku pracy, a ogromnym atutem jest udział w licznych praktykach i stażach zawodowych. Tego typu działania nie tylko pozwalają zdobyć cenne doświadczenie, ale także (co równie ważne dla przyszłych pracodawców) nabyć kompetencje miękkie (umiejętności

6 M. Kocór, A. Strzebońska, M. Dawid-Sawicka, Pracodawcy o rynku pracy. Na podstawie badań zrealizowanych w 2012 roku w ramach III edycji projektu Bilans Kapitału Ludzkiego, Warszawa 2012, s. 9-12. 
organizacyjne, pracy zespołowej, komunikacji, autoprezentacji). Studentom brakuje profesjonalnego poradnictwa zawodowego i wsparcia w przygotowaniu się do poszukiwania pracy, poprawy umiejętności psychospołecznych i aktywizacji zawodowej. Warto, aby uczelnie intensywniej wspierały swoich studentów także w tym zakresie. W przeciwnym wypadku ich aktywność kończyć się będzie na uzyskaniu dyplomu. Uczelnie mogą odegrać również bardzo dużą rolę w budowaniu u pracodawców pozytywnego wizerunku osób z niepełnosprawnościami - studentów i przyszłych pracowników, tak samo zdolnych i kompetentnych jak pełnosprawni.

Niezwykle ważne jest uświadomienie wszystkim członkom środowiska akademickiego oraz osobom mającym wpływ na kształt szkolnictwa wyższego w Polsce, że pełnej dostępności szkolnictwa wyższego dla osób z niepełnosprawnością nie powinno ograniczać się tylko do klasycznie pojmowanego procesu kształcenia. Podkreśla to Konwencja ONZ o prawach Osób Niepełnosprawnych (art. 24 ust. 1 Konwencji) ${ }^{7}$ :

„Państwa Strony uznają prawo osób niepełnosprawnych do edukacji. W celu realizacji tego prawa bez dyskryminacji i na zasadach równych szans Państwa Strony zapewnią włączający system kształcenia umożliwiający integrację na wszystkich poziomach edukacji i w kształceniu ustawicznym, zmierzające do:

(a) pełnego rozwoju potencjału oraz poczucia godności i własnej wartości, a także wzmocnienia poszanowania praw człowieka, podstawowych wolności i różnorodności ludzkiej,

(b) rozwijania przez osoby niepełnosprawne ich osobowości, talentów i kreatywności, a także zdolności umysłowych i fizycznych, przy pełnym wykorzystaniu ich możliwości,

(c) umożliwienia osobom niepełnosprawnym skutecznego udziału w wolnym społeczeństwie".

Współpraca organizacji pozarządowych ze studentami i całym środowiskiem akademickim, służąca szerzeniu wiedzy o niepełnosprawności i prawach studentów z niepełnosprawnościami, jest jednym z głównych działań zwiększających ich szanse i aktywność podczas studiów i w poszukiwaniu zatrudnienia. Budowanie świadomej społeczności studentów z niepełnosprawnościami oraz rozumiejącej ich potrzeby i respektującej prawa społeczności akademickiej przełoży się na późniejszy sukces społeczny

7 Konwencja o prawach Osób Niepełnosprawnych, http://isap.sejm.gov.pl/DetailsServ let?id=WDU20120001169 (dostęp: 30.06.2015). 
238 i zawodowy tych osób. Rozwiązanie problemów ukazanych w tym artykule nie zawsze wymaga dużego nakładu pracy i środków. Najważniejsze często okazuje się usunięcie barier mentalnych. Szeroko pojmowana „dostępność" dotyczy wszystkich aspektów funkcjonowania uczelni i sfer życia akademickiego. Zwiększanie wiedzy na temat specyficznych potrzeb, ale i potencjału studentów z niepełnosprawnościami, uświadomienie znaczenia ich wykształcenia dla przyszłości zawodowej i społecznej, a przede wszystkim wymiana doświadczeń pomiędzy studentami a pełnomocnikami do spraw studentów niepełnosprawnych z wyższych uczelni oraz środowiskiem pracodawców jest najlepszą metodą osiągnięcia celu, jakim jest łatwiejszy dostęp do zatrudnienia na otwartym rynku pracy dla absolwentów z niepełnosprawnościami.

Praktyka pokazuje, że struktury odpowiedzialne za dostosowanie uczelni dla osób z niepełnosprawnościami pozbawione są możliwości płynnej komunikacji na poziomie ogólnopolskim. Prowadzi to do pogłębiania dysproporcji pomiędzy poziomem dostępności, a tym samym marginalizacji edukacyjnej, społecznej oraz w ostateczności zawodowej osób z niepełnosprawnościami zamieszkujących poszczególne regiony kraju. Aby ograniczyć ten problem, corocznie organizujemy ogólnopolską konferencję Pełno(s)prawny Student. Formuła tego działania została opracowana na podstawie wieloletniego doświadczenia FIRR we współpracy ze środowiskiem akademickim i studentami z niepełnosprawnościami w kontekście zwiększania jego dostępności dla osób z niepełnosprawnościami oraz promocji aktywizacji absolwentów z niepełnosprawnościami. Dotychczasowe 8 edycji konferencji zgromadziło w sumie około tysiąca uczestników: osób z niepełnosprawnościami, decydentów, przedstawicieli środowiska oraz przedstawicieli uczelni wyższych, zaangażowanych w proces dostosowywania środowiska akademickiego, pracodawców, instytucji zajmujących się szeroko pojętą problematyką niepełnosprawności (w szczególności związaną z aktywnością zawodową), mediów. Beneficjentami bezpośrednimi są przede wszystkim pełnomocnicy rektorów ds. studentów niepełnosprawnych oraz pracownicy biur ds. studentów niepełnosprawnych. To oni są głównymi inicjatorami zmian w środowisku akademickim na rzecz poprawy sytuacji studentów z niepełnosprawnościami. Doświadczenia FIRR z poprzednich edycji konferencji wskazują, iż chętnie uczestniczą w tego typu przedsięwzięciach w celu wymiany swoich doświadczeń oraz poszukiwania nowych rozwiązań w zapewnianiu wsparcia studentom, także w zakresie możliwości aktywizacji zawodowej. Elementami konferencji, które mają bezpośrednio prowadzić 
do zwiększenia uczestnictwa studentów i absolwentów z niepełnosprawno-

ściami w praktykach i stażach zawodowych oraz zmiany postrzegania ich na rynku pracy, są:

- stworzenie forum dialogu pomiędzy studentami i absolwentami, pracownikami uczelni, przedstawicielami środowiska naukowego, decydentami oraz pracodawcami, umożliwiającego prezentację dobrych praktyk w zakresie wsparcia i przygotowania zawodowego studentów z niepełnosprawnościami,

- zapewnienie dostępu do informacji na temat działań integracyjnych i antydyskryminacyjnych, kierowanych do studentów i absolwentów z niepełnosprawnościami,

- wymiana doświadczeń oraz tworzenie sieci współpracy,

- promocja dobrych praktyk w działaniach wewnętrznych (np. ofertach praktyk i staży studenckich) i zewnętrznych (współpracy z podmiotami rynku pracy) na rzecz aktywizacji zawodowej studentów i absolwentów z niepełnosprawnościami oraz wszelkich działań i rozwiązań integracyjnych, antydyskryminacyjnych, umożliwiających wejście na rynek pracy po zakończonych studiach.

Kolejnym istotnym działaniem są szkolenia świadomościowe z zakresu zwiększenia dostępności uczelni dla studentów z niepełnosprawnościami, przeznaczone dla państwowych i prywatnych uczelni, mające na celu zwiększenie kompetencji ich kadry w zakresie organizacji i realizacji procesu kształcenia studentów z niepełnosprawnościami. Program przykładowego szkolenia, trwającego 6 godzin dydaktycznych, obejmuje następujące zagadnienia:

1. Sytuacja formalnoprawna studentów z niepełnosprawnościami.

2. Metody i środki wspierające osoby z różnymi dysfunkcjami w procesie kształcenia na poziomie szkolnictwa wyższego.

3. Informacja dostępna - efektywne komunikowanie w aspekcie specyficznych potrzeb osób z różnymi rodzajami niepełnosprawności.

4. Urządzenia wspomagające osoby z niepełnosprawnościami.

5. Praktyczne formy wsparcia studentów z niepełnosprawnościami $\mathrm{w}$ warunkach środowiska akademickiego (analiza z zainteresowanymi osobami konkretnych, pojawiających się $\mathrm{w}$ ich codziennej pracy trudności, wynikających ze specyfiki niepełnosprawności ich klientów).

Szkolenia cieszą się dużym zainteresowaniem kadry akademickiej, a zapotrzebowanie na ich organizację nie maleje. Pokazujemy, w jaki sposób technicznie oraz administracyjnie dostosować szkoły i uczelnie wyższe 
240 do potrzeb osób z różnego rodzaju niepełnosprawnościami. Prezentujemy dobre praktyki i skuteczne rozwiązania zebrane podczas wieloletniej współpracy z uczelniami wyższymi. Na szkoleniu przedstawiamy także skąd i jak pozyskuje się dotacje na dostosowanie placówek i systemu nauczania do potrzeb osób z niepełnosprawnościami. W naszej ofercie znajduje się także kurs z zakresu dostępności stron internetowych i dokumentów elektronicznych. Obecne prawo zmierza do zagwarantowania dostępności stron internetowych i dokumentów elektronicznych urzędów publicznych. Wyjaśniamy, co kryje się za tymi przepisami i jak je skutecznie wdrożyć w życie. Dzięki naszym szkoleniom uczestnicy dowiadują się, czym jest dostępność informacji, kogo dotyka brak dostępności, jak wdrażać i zamawiać dostępne serwisy internetowe oraz jak skutecznie używać narzędzi do samodzielnej kontroli dostępności stron internetowych oraz dokumentów. Przede wszystkim prezentujemy korzyści, jakie płyną ze zwiększenia dostępności stron oraz dokumentów, co przekłada się na efektywność komunikacji także na uczelni.

Fundacja Instytut Rozwoju Regionalnego stawia sobie za cel także współpracę ze środowiskiem akademickim w działaniach w obszarze prawa. Znaczącym efektem tej aktywności jest obecny kształt zapisów znowelizowanej Ustawy Prawo o szkolnictwie wyższym ${ }^{8}$, szczególnie art. 13, który brzmi:

1. Podstawowymi zadaniami uczelni, z zastrzeżeniem ust. 2 i 3 , są:

9) stwarzanie osobom niepełnosprawnym warunków do pełnego udziału $\mathrm{w}$ procesie kształcenia i w badaniach naukowych.

Zmiany w prawie determinują szereg zmian w uczelnianej rzeczywistości. W myśl nowelizacji proces dydaktyczny musi brać pod uwagę szczególne potrzeby studentów z niepełnosprawnościami, co powinno być uwzględnione również w regulaminie studiów. Egzaminy wstępne, tam gdzie obowiązują, muszą respektować specyficzne potrzeby niepełnosprawnych kandydatów. Ten wymóg mają spełniać również egzaminy na studia doktoranckie. Standardy kształcenia dla wszystkich nauczycieli powinny być dostosowane do wymogów pracy z uczniami o specjalnych potrzebach edukacyjnych. Zmienił się też przedmiot dotychczasowej dotacji z kształcenia i rehabilitacji leczniczej studentów niepełnosprawnych na „zadania związane ze stwarzaniem studentom i doktorantom, będącym osobami niepełnosprawnymi, warunków do pełnego udziału w procesie kształcenia" (art. 94 ust. 1 pkt. 11).

8 Ustawa z dnia 27 lipca 2005 r. Prawo o szkolnictwie wyższym (Dz.U. Nr 164, poz. 1365, z późn. zm.). http://www.nauka.gov.pl/fileadmin/user_upload/szkolnictwo/Reforma/ 20110523_USTAWA_z_dnia_27_lipca_2005.pdf (dostęp: 30.06.2015). 
Poszerzono ponadto dostęp do dotacji dla uczelni niepublicznych. $Z$ drugiej strony wciąż brakuje kompleksowej wykładni przepisów oraz wystarczających środków na ich wdrażanie. W uzyskiwaniu tej wiedzy staramy się wspierać zainteresowane uczelnie, poruszając ten temat na naszych szkoleniach, konferencjach oraz w rozmowach z Ministerstwem Nauki i Szkolnictwa Wyższego.

W ramach projektu „Prawo w praktyce” (2012-2013) prowadzony był monitoring postępów w realizacji zapisów ustawowych, do których uchwalenia FIRR się przyczyniła. W obszarze szkolnictwa wyższego główny nacisk został położony na prace skupione wokół ustawowo wymaganej zmiany regulaminów studiów pod kątem zapisów o organizacji zajęć i egzaminów dla niepełnosprawnych studentów oraz wprowadzenia do programu studiów nauczycielskich elementów kształcenia w zakresie pedagogiki specjalnej, a tym samym przygotowania przyszłych nauczycieli do pracy z niepełnosprawnym uczniem o specjalnych potrzebach edukacyjnych. Zgodnie z Rozporządzeniem Ministra Nauki i Szkolnictwa Wyższego z dnia 19 lipca 2011 r. w sprawie warunków, jakim muszą odpowiadać postanowienia regulaminu studiów w uczelniach':

$\$ 2$. Regulamin studiów określa sposób dostosowania organizacji i właściwej realizacji procesu dydaktycznego do szczególnych potrzeb studentów będących osobami niepełnosprawnymi, w tym dostosowania warunków odbywania studiów do rodzaju niepełnosprawności.

$\mathrm{W}$ wyniku przeprowadzonego przez FIRR monitoringu okazało się, że zazwyczaj respektowaną zasadą było, iż uczelnia stwarza studentom z niepełnosprawnościami możliwość odbywania studiów według indywidualnego toku studiów i przesunięcia terminu egzaminu w uzasadnionych przypadkach. Niestety $w$ wielu nie znaleziono żadnego zapisu o zobowiązaniach uczelni do zapewnienia studentom z niepełnosprawnościami pełnego dostępu do edukacji wyższej. Wiele uczelni nie udostępniało również swojego regulaminu $\mathrm{w}$ wersji elektronicznej na stronie internetowej, pozostawiając go do wglądu jedynie studentom i tylko na miejscu, co uniemożliwia niepełnosprawnym kandydatom na studia zapoznanie się z dokumentami ich potencjalnie przyszłej uczelni. FIRR służyła wsparciem w zakresie dostosowania zapisów regulaminu, a także dostępności jego wersji elektronicznej.

9 Rozporządzenie Ministra Nauki i Szkolnictwa Wyższego z dnia 19 lipca 2011 r. w sprawie warunków, jakim muszą odpowiadać postanowienia regulaminu studiów w uczelniach, http://isap.sejm.gov.pl/DetailsServlet?id=WDU20111600958 (dostęp: 30.06 .2015 ). 
242 Wyniki monitoringu zostały również przedstawione na konferencji Pelno(s) prawny Student.

Z pewnością do sukcesów współpracy pomiędzy organizacjami pozarządowymi, administracją publiczną, pracodawcami i uczelniami można zaliczyć dwie edycje projektu prozatrudnieniowego „Staż w administracji publicznej wsparciem aktywizacji społecznej i zawodowej osób niepełnosprawnych oraz budowaniem pozytywnego wizerunku osób niepełnosprawnych na rynku pracy", realizowanego w ramach Programu Operacyjnego Kapitał Ludzki, Priorytet I Zatrudnienie i integracja społeczna, Działanie 1.3 Ogólnopolskie programy integracji i aktywizacji zawodowej, Poddziałanie 1.3.6 PFRON projekty systemowe, którego liderem był Państwowy Fundusz Rehabilitacji Osób Niepełnosprawnych. Głównymi celami projektu były podniesienie szans na zatrudnienie osób z niepełnosprawnościami (ponad 400 osób z całego kraju) poprzez udzielenie zindywidualizowanego i kompleksowego wsparcia oraz promocja idei zatrudnienia osób z niepełnosprawnościami w administracji publicznej. Grupą docelową projektu były osoby niepełnosprawne:

- w stopniu znacznym, umiarkowanym oraz lekkim w przypadku niepełnosprawności sprzężonej,

- nieaktywne zawodowo, bezrobotne, poszukujące pracy z terenu całego kraju,

- kobiety w wieku 16-59 lat, mężczyźni w wieku 16-64 lata.

Stażyści rekrutowali się m.in. spośród studentów i absolwentów takich uczelni, jak: Akademia Górniczo-Hutnicza, Politechnika Łódzka, Uniwersytet Adama Mickiewicza w Poznaniu, Uniwersytet Pedagogiczny w Krakowie, Uniwersytet Śląski, Uniwersytet Warszawski.

W ramach projektu zapewniono:

- opracowanie indywidualnego planu stażu dla wszystkich uczestników (uczestniczek) projektu,

- 3-miesięczne staże rehabilitacyjne dla wszystkich uczestników (uczestniczek) projektu w organach administracji publicznej i jednostkach im podległych,

- dla co najmniej 50 proc. uczestników (uczestniczek) ukończenie szkoleń zawodowych, podnoszących kwalifikacje,

- wsparcie trenera pracy, doradcy zawodowego i psychologa oraz specjalistów różnych dziedzin,

- szkolenia informacyjno-świadomościowe dla pracowników organizatora stażu, w trakcie których doświadczeni trenerzy poruszali zagadnie- 
nia dotyczące osób z niepełnosprawnościami w pracy i barier, z jakimi

się spotykają.

Wśród najciekawszych miejsc stażowych można wymienić następujące: Kancelaria Prezesa Rady Ministrów w Warszawie, Prokuratura Okręgowa w Łodzi, Prokuratura Okręgowa w Krakowie, urzędy marszałkowskie województw: śląskiego, małopolskiego, dolnośląskiego i mazowieckiego, Kuratorium Oświaty w Warszawie, Naczelna Dyrekcja Archiwów Państwowych w Warszawie, Wojewódzki Inspektorat Ochrony Środowiska w Łodzi, Muzeum Historii Żydów Polskich w Warszawie. Co bardzo cieszy, część beneficjentów projektu została zatrudniona właśnie w miejscu odbywania stażu. Z dobrymi praktykami wypracowanymi w projekcie stażowym i historiami stażystów można się zapoznać, korzystając z publikacji Dobre praktyki w zakresie zatrudniania osób z niepełnosprawnościami w sektorze publicznym.

Działania te są obecnie kontynuowane w projekcie „Staż w administracji publicznej drogą do zatrudnienia na otwartym rynku pracy" (projekt współfinansowany ze środków PFRON, okres realizacji: 01.04.201531.03.2016, partnerzy: Uniwersytet Marii Curie-Skłodowskiej w Lublinie, Uniwersytet Warszawski, Akademia Górniczo-Hutnicza, Uniwersytet Pedagogiczny im. KEN, Specjalny Ośrodek Szkolno-Wychowawczy dla Niesłyszących im. J. Korczaka w Krakowie).

Warto wspomnieć również o wypracowywaniu nowych rozwiązań we współpracy z zagranicznymi partnerami. Realizacja projektów współfinansowanych ze środków Unii Europejskiej jest wielką szansą na rozwój zarówno polskich organizacji pozarządowych, jak i uczelni. Projekt „Europejscy Mistrzowie Cyfrowego Włączenia” (transfer innowacji w ramach programu Leonardo da Vinci), w którym partnerami Fundacji Instytut Rozwoju Regionalnego są organizacje z Belgii, Bułgarii i Irlandii, ma na celu ułatwienie osobom z niepełnosprawnościami nabywania umiejętności cyfrowych, niezbędnych w edukacji i zatrudnieniu na otwartym rynku pracy. Aby stało się to możliwe, stworzymy internetową społeczność, opartą na modelu sieci wzajemnego wsparcia. Miejscem wirtualnych spotkań będzie platforma DigiPlace4All (https://digiplace4all.eu/). DigiPlace4All to przestrzeń funkcjonowania wirtualnej społeczności osób z niepełnosprawnościami, nauczycieli akademickich, trenerów zawodowych oraz pracodawców. Wirtualną społeczność podtrzymywać, rozbudowywać i promować będą jej członkowie. Kanały komunikacyjne, dostępne na platformie, umożliwią nawiązywanie i nieustannie wzmacnianie relacji, aby dzielić doświadczenia, 
244 wiedzę i umiejętności, co zapewni istnienie zawsze dostępnego i aktualnego źródła informacji i wsparcia w zakresie dostępności edukacji i zatrudnienia. Sukces DigiPlace4All zależy od aktywności i zaangażowania jego użytkowników. Dzięki rejestracji na platformie uczelnia może zyskać:

- nowe narzędzie współpracy z pracodawcami i sektorem pozarządowym;

- wsparcie swoich działań na rzecz zwiększania dostępności edukacji dla osób z niepełnosprawnościami;

- nowe narzędzie komunikacji między pracownikami uczelni a studentami z niepełnosprawnościami.

Udział studentów w budowaniu społeczności DigiPlace4All to także możliwość promowania działań uczelni oraz okazja do wzmocnienia więzi społeczności akademickiej. Wyrażamy nadzieję, że DigiPlace4All stanie się w niedalekiej przyszłości ogólnodostępnym, trwałym źródłem wzajemnego wsparcia, przekładającym się na wzrost włączenia cyfrowego osób z niepełnosprawnościami w całej Polsce.

Na zakończenie krótkiego opisu działań Fundacji Instytut Rozwoju Regionalnego we wspieraniu kształtowania środowiska akademickiego przyjaznego osobom z niepełnosprawnościami oraz zwiększaniu szans zawodowych absolwentów z niepełnosprawnościami zamieszczam spis publikacji, jakie oferujemy m.in. pracownikom uczelni wyższych i studentom:

- Dobre praktyki. Zapisy regulaminu dotyczące organizacji i realizacji procesu dydaktycznego z uwzględnieniem potrzeb studentów niepetnosprawnych,

- Adaptacja materiałów informacyjnych,

- Adaptacja stanowiska komputerowego,

- Uczelnia dostępna. Organizacja systemu wsparcia. Lektoraty języków obcych,

- Wskazówki dla osób prowadzacych zajęcia dydaktyczne ze studentami z niepetnosprawnościa mowy/stuchu/wzroku.

Wszystkie poradniki są dostępne na licencji Creative Commons Uznanie autorstwa 2.5 Polska i można je pobrać ze strony internetowej Fundacji: www. firr.org.pl, do czego serdecznie zachęcamy. 
Role of non-governmental organizations in fostering the shaping

of "people with disabilities friendly" academe and enhancing professional chances of graduates with disabilities

Foundation Institute for Regional Development is Polish NGO active in the field of disability. We support people with disabilities in their independent lives with trainings and advisory. We promote full participation in society, including inclusive education. We cooperate with Parliament, local governments, universities and employers. We would like to introduce you our long-term activities for increasing the accessibility of colleges for persons with disabilities. Crucial areas are: advocacy and legislative activity, increasing the awareness of the academic staff and the administrative staff in the area of functioning of students with different kinds of disability through trainings, research activity, conferences, seminars, thematic meetings, publishing thematic publications, the implementation of projects, referred to students and graduates of colleges, concentrated on improving their professional potential and self-reliance on the open labor market.

Keywords: disability, accessibility, inclusive education, open labor market

Rola organizacji pozarządowych we wspieraniu kształtowania środowiska akademickiego przyjaznego osobom

z niepełnosprawnościami oraz zwiększaniu szans zawodowych absolwentów z niepełnosprawnościami

Fundacja Instytut Rozwoju Regionalnego to polska organizacja pozarządowa, działająca na rzecz osób z niepełnosprawnościami. Poprzez szkolenia i doradztwo wspieramy ich niezależność. Promujemy pełny udział w życiu społecznym, w tym edukację włączającą. Współpracujemy z Parlamentem, samorządami, uczelniami i pracodawcami. Przedstawiamy Państwu naszą długoletnią działalność na rzecz zwiększenia dostępności uczelni wyższych dla osób z niepełnosprawnościami. Jej obszary kluczowe to: rzecznictwo i działania legislacyjne, zwiększanie świadomości pracowników akademickich i pracowników administracyjnych w zakresie funkcjonowania studentów z różnymi rodzajami niepełnosprawności poprzez szkolenia, działalność badawczą, konferencje, seminaria, spotkania tematyczne, publikacje; realizacja projektów skierowanych do studentów i absolwentów szkół wyższych, wzmacniających ich potencjał zawodowy i samodzielność na otwartym rynku pracy.

Słowa kluczowe: niepełnosprawność, dostępność, edukacja włączająca, otwarty rynek pracy 


\section{Bibliografia}

Główny Urząd Statystyczny, Badanie Aktywności Ekonomicznej Ludności 2007-2014, http://stat.gov.pl/informacja-o-badaniach-ankietowych/badanie-aktywnosci-eko nomicznej-ludnosci-bael/ (dostęp: 30.06.2015).

European Commission, Europe 2020. A strategy for smart, sustainable and inclusive growth, Brussels, 03.03.2010, COM (2010) 2020, http://ec.europa.eu/eu2020/ pdf/COMPLET\%2OEN\%2OBARROSO\%20\%20\%20007\%20-\%20Europe\%2020 20\%20-\%20EN\%20version.pdf (dostęp: 30.06.2015).

Zgromadzenie Ogólne Narodów Zjednoczonych, Konwencja o prawach Osób Niepełnosprawnych, Dz.U. z dnia 25 października 2012 r., poz. 1169.

Kocór M., Strzebońska A., Dawid-Sawicka M., Pracodawcy o rynku pracy. Na podstawie badań zrealizowanych w 2012 roku w ramach III edycji projektu Bilans Kapitału Ludzkiego, Warszawa 2012.

Klyszcz L., Pułapka świadczeniowa a aktywność zawodowa i społeczna osób niepełnosprawnych, Kraków 2011.

Uchwała nr 104 Rady Ministrów z dnia 18 czerwca 2013 r. w sprawie przyjęcia Strategii Rozwoju Kapitału Ludzkiego 2020, Dziennik Urzędowy Rzeczypospolitej Polskiej, 07.08.2013, poz. 640.

Ustawa z dnia 27 lipca 2005 r. Prawo o szkolnictwie wyższym, Dz.U. Nr 164, poz. 1365.

Rada Unii Europejskiej, Zalecenie Rady w sprawie krajowego programu reform Polski z 2013 r. oraz zawierające opinię Rady na temat przedstawionego przez Polskę programu konwergencji na lata 2012-2016, Dziennik Urzędowy Unii Europejskiej, 2014/C 247/19. 